\title{
Evaluation of coppe slag as aggregate addition on properties of cementitious matrix
}

Cézar Augusto Casagrande ${ }^{1}$, Diego Deyvison dos Santos ${ }^{1}$, Lidiane Fernanda Jochem ${ }^{2}$, Ana Cecília de Nóbrega ${ }^{1}$

\footnotetext{
${ }^{1}$ Federal University of Pernambuco, Technology Core of Campus Agreste (NT-CAA), Av. Campina Grande, s/n, Km 59, Nova Caruaru, CEP: 55014-900, Caruaru, PE, Brazil.

${ }^{2}$ Federal Technological University of Paraná (UTFPR), Civil Construction Academic Department (DACOC), Campus Ecoville, Street Deputado Heitor Alencar Furtado, 5000, CEP: 81280-340, Curitiba, PR, Brazil.

e-mail: cezar.acasa@gmail.com, diegosantos367@hotmail.com, lidijochem@gmail.com, anacecilianobrega@gmail.com.
}

\begin{abstract}
This work aims the performance of concretes copper slag-added evaluated in fresh state by slump test and in hardened state by compression strength in 7 and 28 days of cement hydration, durability indexes as water absorption and binder efficiency by cement index. In fresh state, the results showed that the samples with copper slag presented lower slump than the reference sample. In hardened state, with $30 \%$ of copper slag addition, the compression strength was reduced only by $9 \%$ and $8 \%$ in comparison with the control series, for 7 and 28 days, receptively. Also, for 28 and 48 days of cement hydration, the water absorption showed lower values in the series with copper slag, indicating a beneficial performance of this waste in the cementitious matrix. Also, the binder efficiency was verified in the work. As the higher the slag in the mixture, lower was the cement consumption and, consequently, higher was the efficiency of the cement, resulting in a low increased in the cement index. The control series, at 28 days of cement hydration, achieved $11 \mathrm{~kg} \cdot \mathrm{m}^{-3} \cdot \mathrm{MPa}^{-1}$ while the $30 \%$ copper slag-added series achieved $12 \mathrm{~kg} \cdot \mathrm{m}^{-3} \cdot \mathrm{MPa}^{-1}$, which is only $9 \%$ higher than series with no consumption of copper slag, indicating a great performance of the copper slag in this cementitious matrix.
\end{abstract}

Keywords: copper slag; cementitious matrix; replacement; concrete.

\section{INTRODUCTION}

Copper slag is a waste derived from the production of copper alloys, where more than 30 million tons are generated annually around the world [1]. It is a product composed of less than $3 \%$ of copper, partially amorphous and when composed of calcium oxide, aluminum, magnesium and, mainly, silica in appropriate proportions, may have interesting pozzolanic properties for the cementitious matrix [2].

The cement and concrete industry is one of the largest contributors to CO2 emissions today [3, 4]. Since the 2000s, alternatives have been implemented to reduce their impact on pollutant emissions [5]. One of the most popular approaches is to improve the dosage of concrete by manipulating its constituents $[6,7]$. Another widely used alternative is the progressive consumption of synthetic and organic additives in order to reduce cement consumption per unit volume [8]. In addition, one approach that is increasingly being employed is the partial replacement of cement and or aggregates by some industrial waste or byproduct, as slag, ash, bricks, clays, glass, kaolinite, heavy metals, organic waste and others [9-17].

Nowadays, most industrial cement already present in their composition some mineral addition from some industrial process that generates a usable byproduct in the cement production [18, 19]. In this same perspective, studies have been presented using the replacement of some constituent of the cement matrix by some industrial waste or byproduct. In general, the focus is on replacing cement, which has the greatest energy impact. However, the substitution of other aggregates is also the focus of research. Most substitutions are with pozzolanic potential materials such as silica-rich residue, slag and ash. Also, copper slag residues are also an alternative for incorporation into the cementitious matrix [2].

FENG et al. [1] incorporated CaO-modified copper slag to enhance the reaction by pozzolanic effect in the cementitious matrix and found that with the incorporation of CS maintenance of mechanical properties at 90 days of hydration. A hydrating heat-lowering effect was also found in samples with modified slag. 
PAVEZ et al. [20] partially replaced the cement in three types of mortar with copper slag and found that in general, up to $10 \%$ of substitution there was no significant loss of mechanical properties.

However, higher substitutions did not show promising results. DOS ANJOS et al. [21] incorporated $20,40,60,80$ and $100 \%$ of copper slag as aggregates in substitution of sand in the cementitious matrix and verified 5 to $15 \%$ loss of mechanical strength with the presence of copper slag in the concrete.

GUPTA et al. [22] incorporated copper slag into self-compacting concretes to replace up to $100 \%$ of the sand and found that the flowability of the concretes increased compared to the control sample. In general, mechanical strength increased or maintained at 90 days of hydration due to improved cement hydration, verified by SEM/EDS. WU et al. [23] and AL-JABRI et al. [24] incorporated copper slag as a partial sand substitute in high performance concretes. They found that the strength decreased as a function of the amount of slag and at the same time the slump increased as a function of the residue presence. SHI et al. [25] added copper slag to concrete in up to $100 \%$ of the sand and found that, in general, mechanical strength decreases as a function of the amount of slag present in the matrix. However, there was no behavior trend when the water/binder ratio of the composite varied.

This work proposes the use of copper slag from a local industry (Caruaru/PE-Brazil; Agreste region of the Pernambuco state) as an additional constituent in normal strength plastic concrete ( $<50 \mathrm{MPa})$. From this perspective, the study was conducted in order to make progressive additions of the residue to the mixture in relation to the amount of natural sand. The properties of the concretes were measured in the fresh state, in the hardened state by the compressive strength (in 7 and 28 days), durability indicators as water absorption and efficiency indicators as cement index $\left(\mathrm{kg} \cdot \mathrm{m}^{-3} \cdot \mathrm{MPa}^{-1}\right)$.

\section{EXPERIMENTAL}

For the experimental study, a Brazilian cement CP V ARI was used, in accordance with NBR 16697 [18], equivalent to Type III of ASTM C150 [26]. The cement characteristics are presented in Table 1.

Table 1: Cement properties.

\begin{tabular}{|c|c|c|c|}
\hline \multirow{5}{*}{ 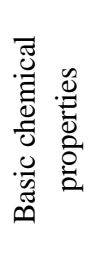 } & CHARACTERISTIC & \multicolumn{2}{|c|}{ AVERAGE (\%) } \\
\hline & Loss ignition & \multicolumn{2}{|c|}{5.03} \\
\hline & Insoluble residue & \multicolumn{2}{|c|}{1.68} \\
\hline & $\mathrm{SO}_{3}^{-}$ & \multicolumn{2}{|c|}{2.50} \\
\hline & $\mathrm{CaO}$ free & \multicolumn{2}{|c|}{1.25} \\
\hline \multirow{9}{*}{ 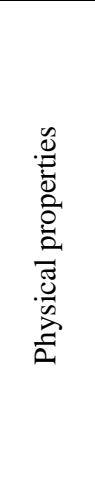 } & CHARACTERISTIC & & \\
\hline & Compression strength (MPa) & 1 day & 18.16 \\
\hline & & 3 days & 28.73 \\
\hline & & 7 days & 37.36 \\
\hline & Specific gravity $\left(\mathrm{g} \cdot \mathrm{cm}^{-3}\right)$ & \multicolumn{2}{|c|}{3.12} \\
\hline & Blaine $\left(\mathrm{cm}^{2} \cdot \mathrm{g}^{-1}\right)$ & \multicolumn{2}{|c|}{4.59} \\
\hline & Setting (min.) & & \\
\hline & \multirow[t]{2}{*}{ Setting (min.) } & Start & 132.86 \\
\hline & & end & 176.90 \\
\hline
\end{tabular}

The sand used is a natural river sand (NS), rich in quartz with a specific gravity of $2.53 \mathrm{~g} \cdot \mathrm{cm}^{-3}$, finesses modulus of 2.70 and a maximum diameter of $4.75 \mathrm{~mm}$. Its particle size distribution is presented in Figure 1. The coarse aggregate is a ground granite stone with a specific gravity of $2.60 \mathrm{~g} \cdot \mathrm{cm}^{-3}$, finesses modulus of 7.08 and maximum diameter of $25 \mathrm{~mm}$. Its particle size distribution is also presented in Figure 1.

The copper slag (CS) was obtained from an industry of metallic structural pieces located in Caruaru/Brazil, and its slag is generated in the fabrication process. The copper slag is used in the blasting and rust removal on metal parts as an abrasive material. The CS presents a specific gravity of $3.81 \mathrm{~g} \cdot \mathrm{cm}^{-3}$, finesses modulus of 4.27 and a maximum diameter of $4.75 \mathrm{~mm}$. Its particle size distribution is presented in Figure 1, Figure 2 and its chemical composition is presented in Table 2.

The main objective of the study was the evaluation of the CS as a constituent of cementitious 
matrixes. For this, three compositions of aggregate were evaluated. The CS was added to NS in three different proportions, 10, 20 and $30 \%$ in weight, and the finesses modulus is 2.42, 2.51 and 2.62, respectively, the particle size distribution of the composed aggregates is presented in Figure 1.

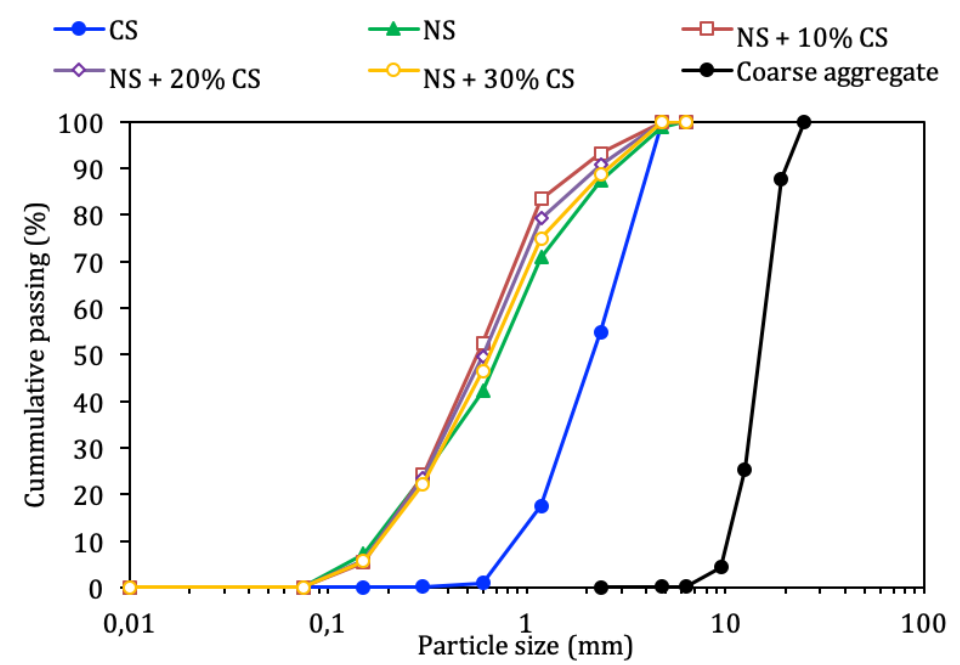

Figure 1: Particle size distribution of the materials used.

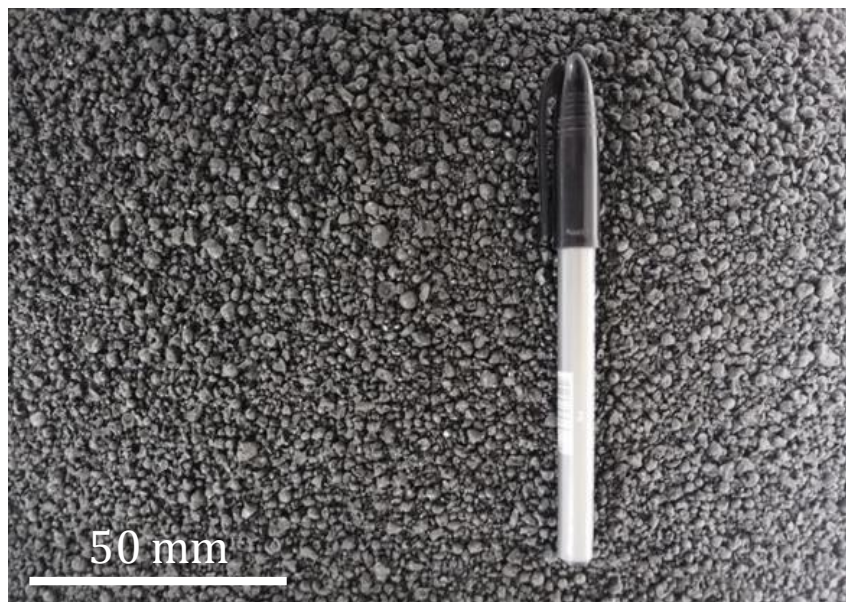

Figure 2: Copper slag used in this research.

Table 2: Copper slag chemical properties.

\begin{tabular}{c|c}
\hline COMPOUND & MASS (\%) \\
\hline $\mathbf{M g O}$ & 1.17 \\
\hline $\mathbf{A l}_{\mathbf{2}} \mathbf{O}_{\mathbf{3}}$ & 3.96 \\
\hline $\mathbf{S i O}_{\mathbf{2}}$ & 25.43 \\
\hline $\mathbf{P}_{\mathbf{2}} \mathbf{O}_{\mathbf{5}}$ & 0.12 \\
\hline $\mathbf{S O}_{\mathbf{3}}$ & 1.26 \\
\hline $\mathbf{K}_{\mathbf{2}} \mathbf{O}$ & 1.01 \\
\hline $\mathbf{C a O} \mathbf{O}$ & 2.41 \\
\hline $\mathbf{F e}_{\mathbf{2}} \mathbf{O}_{\mathbf{3}}$ & 60.45 \\
\hline $\mathbf{C u O}$ & 1.46 \\
\hline $\mathbf{Z n O}$ & 1.60 \\
\hline $\mathbf{A s}_{\mathbf{2}} \mathbf{O}_{\mathbf{3}}$ & 0.18 \\
\hline $\mathbf{M o O}_{\mathbf{3}}$ & 0.91 \\
\hline
\end{tabular}




\begin{tabular}{l|l} 
LOI & 0.04
\end{tabular}

The concretes were produced with the composition of aggregates and water/binder ratio constant and only the copper slag was variable. The concretes proportions are presented in Table 3.

Table 3: Concrete proportion.

\begin{tabular}{c|c|c|c|c|c}
\hline NAME & CEMENT & NS & CS & COARSE AGGREGATE & WATER \\
\hline $\mathbf{0 \%}$ & 1 & 2.84 & 0 & 2.72 & 0.63 \\
\hline $\mathbf{1 0} \%$ & 1 & 2.84 & 0.28 & 2.72 & 0.63 \\
\hline $\mathbf{2 0} \%$ & 1 & 2.84 & 0.56 & 2.72 & 0.63 \\
\hline $\mathbf{3 0} \%$ & 1 & 2.84 & 0.85 & 2.72 & 0.63 \\
\hline
\end{tabular}

Note: Weight unitary proportion.

For fresh state characterization, the slump measurement according to ABNT NM 67 [27] was performed. For hardened state, compression strength at 7 and 28 days in 10x20 cm (diameter x height) cylindrical specimens were performed, for each series, at least three samples were tested, according to NBR 5739 [28]. The samples were cured immersed in water right after demolding until the mechanical test. Also, in the hardened state, water absorption by immersion was determined, according to NBR 9778 [27]. The capillarity absorption was determined according to NBR 9779 [29], in 3, 6, 24 and 48 hours of data collection. Also, specific gravity in the hardened state was performed by the gravimetric method.

\section{RESULTS AND DISCUSSION}

In Figure 3 is presented the slump test of the concretes produced with CS. It is possible to verify that all samples with the addition of CS had a lower slump value compared to the control sample $(0 \%)$. The are some causes that may result in lower workability performance, as the higher the aggregate presence in the mixture, the higher is the necessity of the admixtures or water to guarantee the same workability of the control series. Also, the CS presented a different granulometry than natural sand, also the surface texture of the CS is rougher (due to its production being by blasting which results in fractured particles) than the smooth surface of the natural sand (due to the natural friction of the aggregates in the riverbed and by the weathering), then presents higher specific surface that needs to be wet to flow inside of the mixture, this consume part of the water and reduces the workability of the sample. This may interlock the thin aggregate and difficult to flow, that reflected in lower value in the slump test.

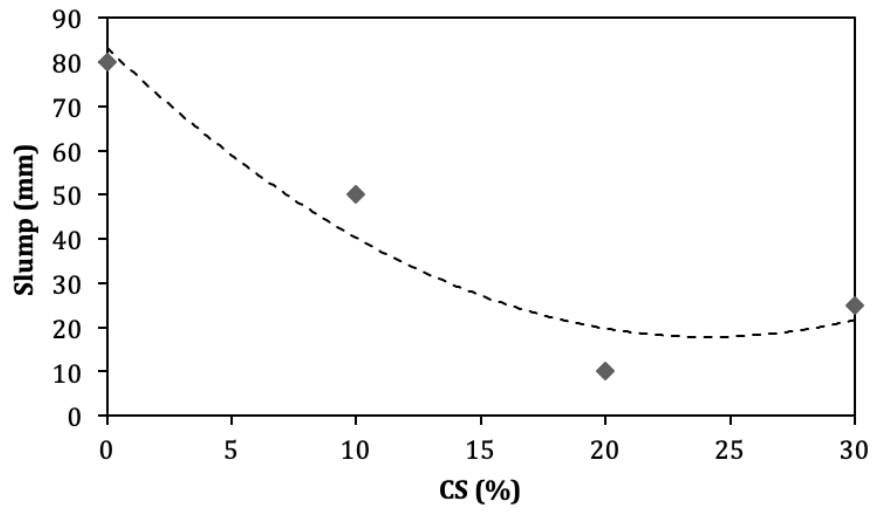

Figure 3: Slump tests of the concretes.

In addition, it is worth mentioning that the CS was add on mass, and has a specific gravity about $50 \%$ higher than the NS, this leads to a reduction in binder volume as the replacement level increases. This fact can result in reductions in workability due to water adsorption to the additionally incorporated particles [30, 31]. The results found here were different than found in [23, 32, 22] that found higher flowability of the concretes as the higher amount of the CS in the mixtures. This may be explained by the characteristic of the CS used in this research, where the particles come from blasting, which results in irregular particles and with 
a large surface area, subject to interaction with the mixing water and admixture, responsible for the initial workability in the concrete mixture.

In Figure 4 is presented the average water absorption by immersion of the concretes produced with CS. According the ANOVA one-way (F-test: 1.26; p-value: 0.34), it is observed that there is no significant variation of water absorption for concretes with the addition of 10, 20 and 30\% compared to the control series for 7 days of cement hydration. Even the cement used is an early strength, for 7 days of cement hydration, the absorption by immersion showed no change as the higher the CS addition in the mixture. This may due to the progressive hydration of the cement particles that still remain in the samples.

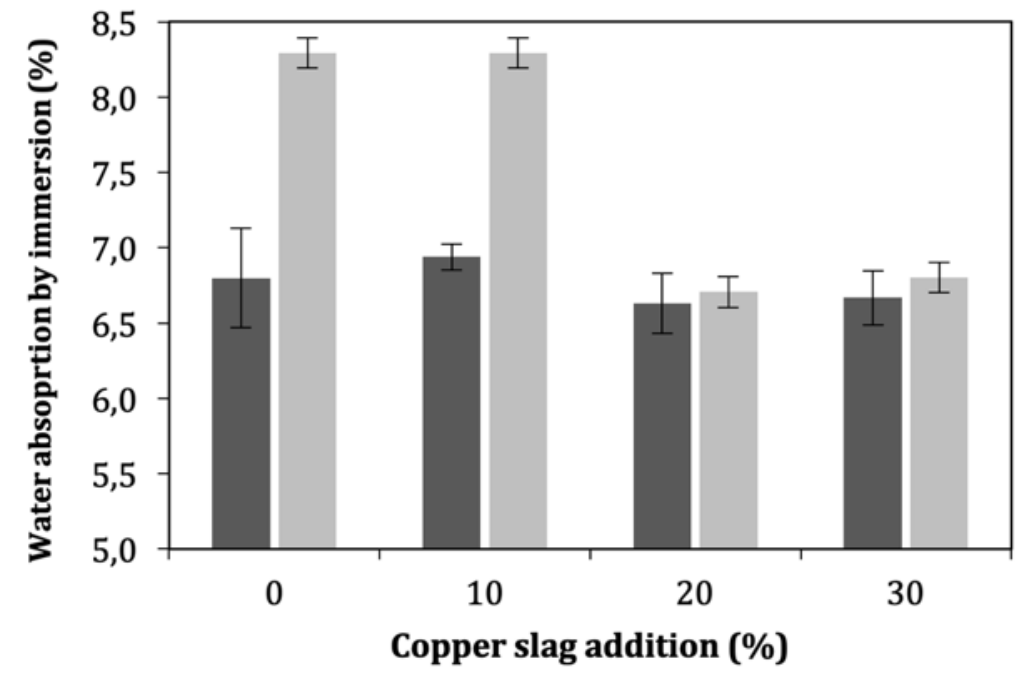

Figure 4: Average values of water absorption by immersion in 7 (dark gray) and 28 (light gray) days with $0,10,20 \mathrm{e}$ $30 \%$ of CS addition. The error bars stand to the standard deviation.

However, at 28 days of cement hydration, there was a great reduction in the water absorption by immersion for the 20 and 30\% CS-added series, which is divergently found by MOURA et al. [33], but is in line with [34], that found a reduction in water absorption with the evolution of the cement hydration for CSadded concrete samples. This may due to the better packing of the mixture with the CS presence, which may improve the compactness and homogeneity of the cement paste. Also, as the higher amount of the CS in the samples, lower is the quantity of the water per cubic meter in the sample, and this resulted in a lower real water/binder ratio in comparison with the control series. This may provide a more compact matrix with less porosity, reflecting in lower water absorption.

In

Figure 5 is presented the water absorption by capillarity in 3, 6, 24 and 48 hours of the concretes produced with CS at 7 and 28 days. For the test at 7 days (

Figure $\mathbf{5}$ (a)) is possible to note that there no significant change in the capillarity absorption between the series in relation of sample control, and a characteristic behavior is noted. For 3 and 6 hours, the control series is less porous than the CS-added series and for 24 and 48 hours, the CS-added series adsorbed lower values than the control series. Only for 48 hours is noted a significant decrease in the water absorption by the $30 \%$ CS-added concrete. Was verified a $10.15 \%$ reduction in the capillarity absorption. The copper slag concrete presented a decrease in porosity. It is related to filler and pozzolanic effect activity that fills copper slag concrete microstructure space promoting reduction and discontinuity of capillary pores and packing matrix. It contributed to pore refinement by increasing the amount of smaller pores and decreasing the amount of the bigger ones. This suggests that for early age, the cementitious matrix present a similarity of the continuous phase (the cement paste) and the real change is more pronounced in later ages of cement hydration [35]. 

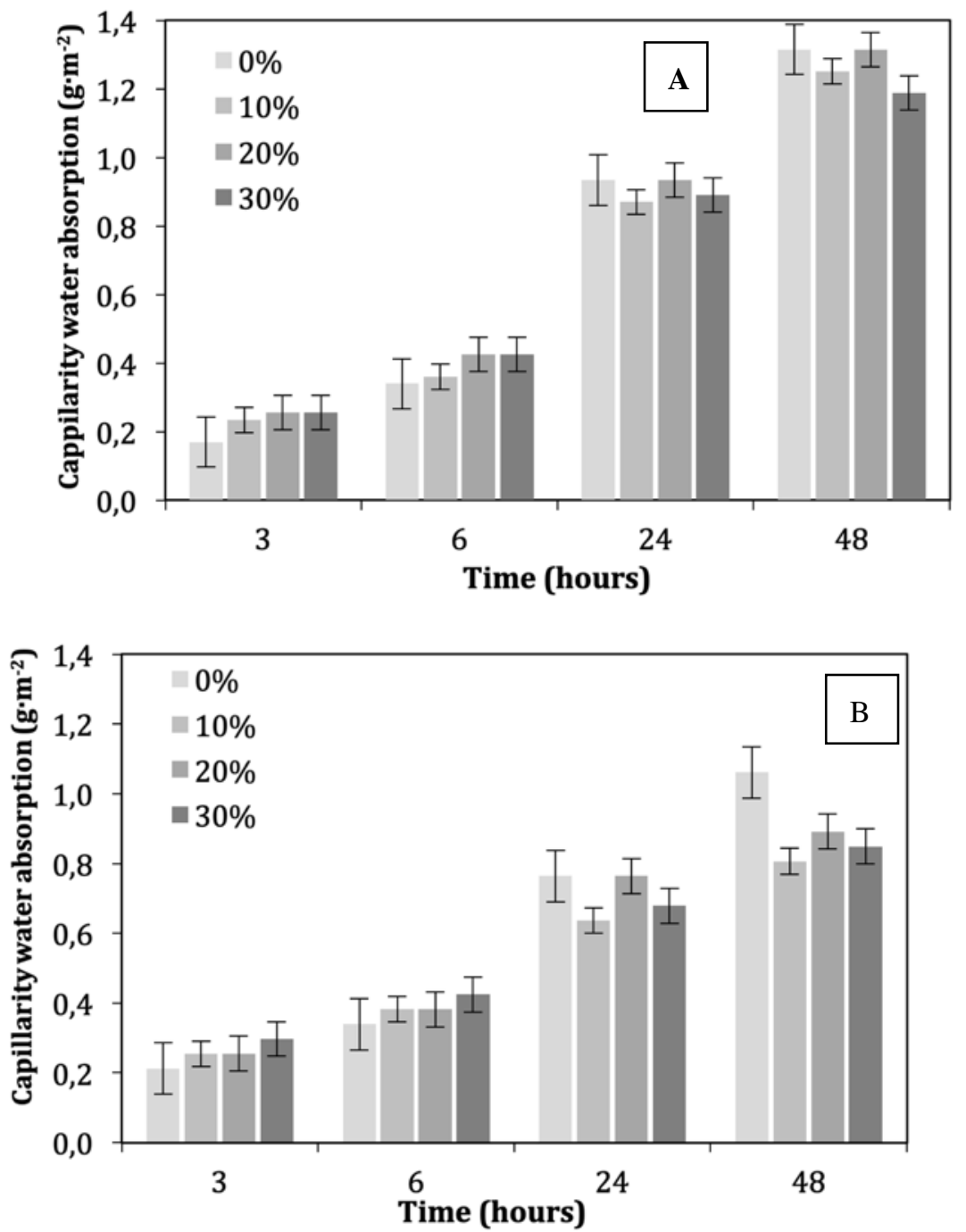

Figure 5: Water absorption by capillarity in the concretes with $0,10,20$ e $30 \%$ of CS addition at 7 days (a) and 28 days (b). The error bars stand to the standard deviation.

The same trend was verified in the 28 day tests. For 3 and 6 hours, the control series adsorbed by capillarity a lower quantity of water than CS-added series. For 24 and 48 hours, the CS-add series adsorbed higher values than the control series. However, according the results of the ANOVA one-way (Table 4), in the 28 days series was verified a statistic significant reduction (F-test: 6.611 and p-value: 0.037; with 95\% of confidence) in the capillarity absorption in the samples for a 48-hour test, which is in line with [21] and that is divergent that found by MOURA et al. [33]. These results also suggest that for early ages, 7 days of cement hydration or for few hours of water contact, the absorption is very intense, mainly due the macroporosity of the cementitious matrix. This means that the difference is verified for long time of cement hydration times or for long time of water contact, that favor the absorption of water by bulk of the cementitious matrix. This also reinforced the suggestion that for higher cement hydration times, the addition of copper slag is beneficial for some durability properties, once the durability is associated with permeable properties of the cementitious matrix $[25,32,33]$. 
Table 4: Results of ANOVA one-way of the capillary water absorption.

\begin{tabular}{|c|c|c|c|c|}
\hline \multirow{2}{*}{ HOURS } & \multicolumn{2}{|c|}{ 7D } & \multicolumn{2}{|c|}{ 28D } \\
\hline & F-test & p-value & F-test & p-value \\
\hline 3 & 2.867 & 0.104 & 1.333 & 0.330 \\
\hline 6 & 1.308 & 0.337 & 1.333 & 0.330 \\
\hline 24 & 1.000 & 0.441 & 2.250 & 0.160 \\
\hline 48 & 2.538 & 0.130 & 4.611 & 0.037 \\
\hline
\end{tabular}

To verify the water distribution configuration for the capillarity absorption, three samples of each series were slept by diametrical test. Figure 6 presents the transversal section of the samples in 7 and 28 days of cement hydration in $0,10,20$ and $30 \%$ of copper slag addition.
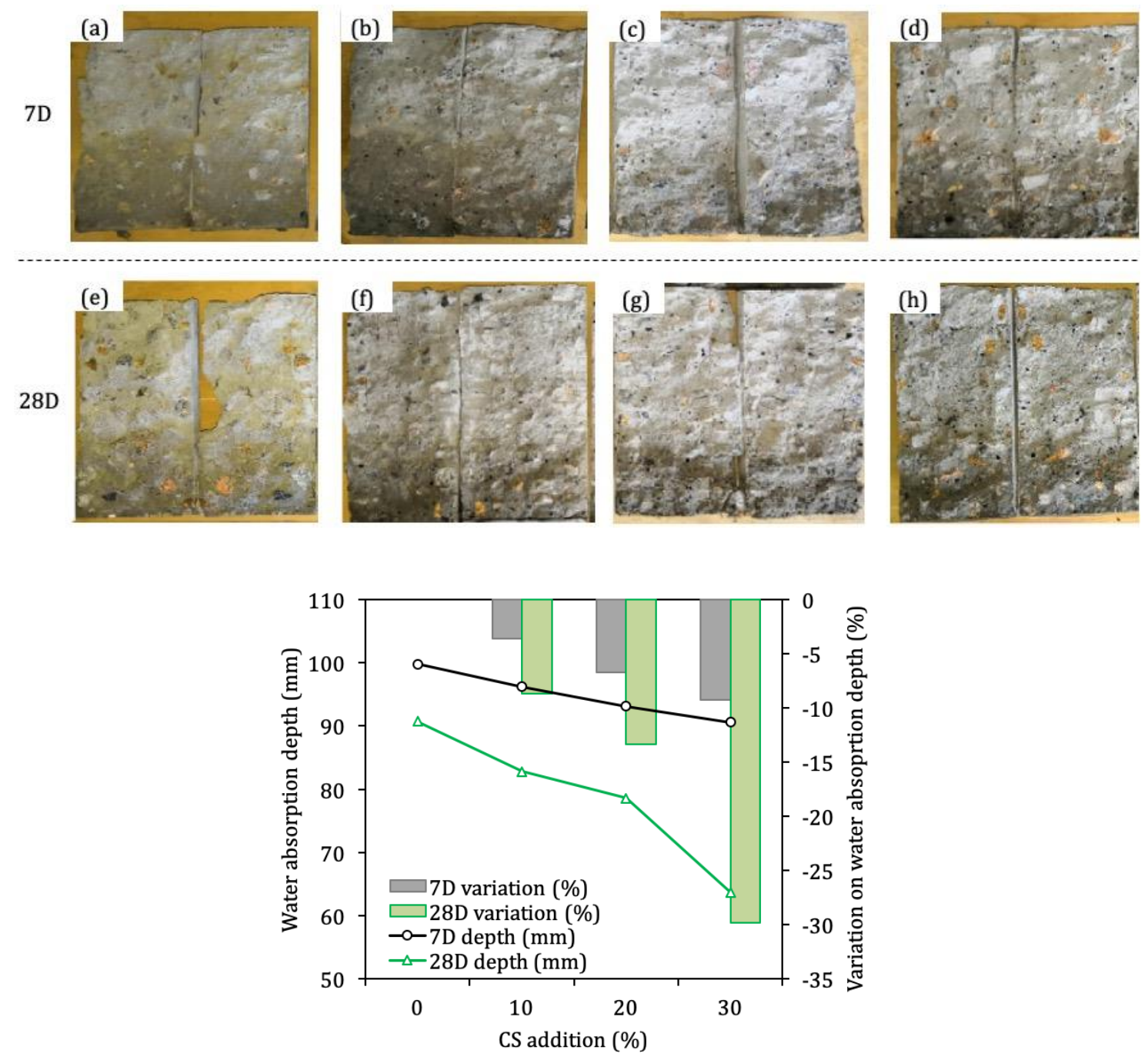

(i)

Figure 6: Diametrical splitted samples of the concretes with 7 days and $0 \%, 10 \%, 20 \%$ and $30 \%$ of CS addition in (a), (b), (c), and (d), respectively, and 28 days in (e), (f), (g), (h), for $0 \%, 10 \%, 20 \%$ and $30 \%$ of CS addition, respectively; (i) Water absorption depth and variation of water absorption depth in comparison with control series. 
It is possible to note that for the concrete in this work, the capillarity absorption is quite relevant. Is verified more than $20 \mathrm{~mm}$ of water impregnation in the samples, that in most of the cementitious matrix structures would in contact with the reinforced steel of the reinforced concrete. However, according Figure 6 (i), for the CS-added concretes, is possible to note that that the depth of the water adsorption is lower than the control series. The control series presented $99.8 \mathrm{~mm}$ and $90.7 \mathrm{~mm}$ of water absorption depth, for 7 and 28 days of cement hydration, respectively, and the $30 \%$-added series presented $90.6 \mathrm{~mm}$ and $63.7 \mathrm{~mm}$ for 7 and 28 days, respectively. This suggests that the CS addition was beneficial to the cementitious matrix. In line with the water absorption results observed.

In Figure 7 is presented the specific gravity of the concretes produced with CS at 7 and 28 days of cement hydration. In general, in the hardened state for 7 and 28 days, as the higher the CS amount in the mixture, the higher was the specific gravity. This is a result of the specific gravity of the CS, which is higher than the NS, also found in $[33,23,21,36]$.

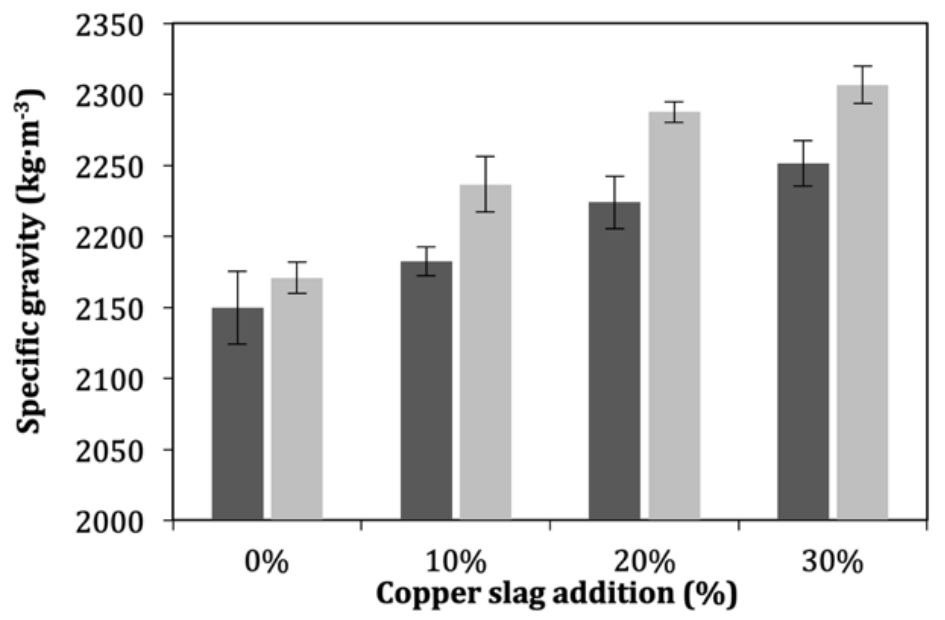

Figure 7: Specific gravity for 7 days (dark gray) and 28 days (light gray), for $0 \%, 10 \%, 20 \%$ e $30 \%$ of CS addition. Errors bars stand to standard deviation.

In general, as the higher the specific gravity, the higher the strength properties. However, in cementitious matrixes, the strength is also dependent on the compact and homogeneity of the cementitious matrix. Here we verified that $30 \%$ of the CS-added sample does not present the lowest water absorption, that suggest that there no direct relation of the CS addition with the homogeneity of the matrix (Figure 8). Then, only the specify gravity may not represent final mechanical properties of the composite.

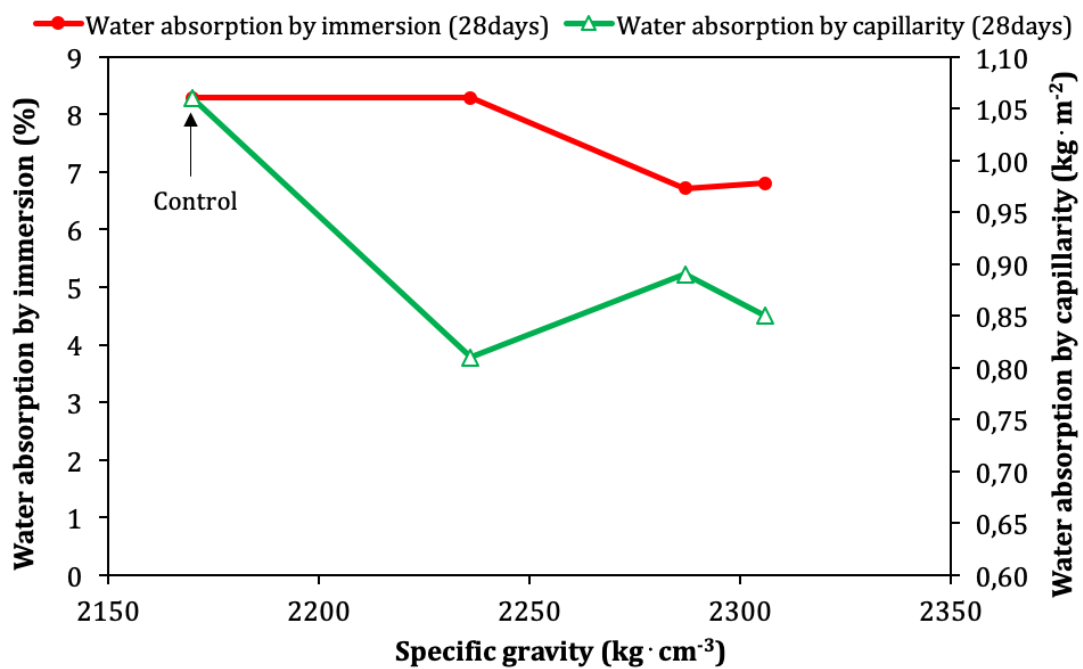

Figure 8: Correlation between specific gravity and water absorption for the CS-added concretes in 28 days of cement hydration. 
In Figure 9 is presented the compression strength of the concretes produced with CS at 7 and 28 days of cement hydration. The error bars correspond to \pm 1 standard deviation. The control concrete series showed the highest compressive strength at both hydrations times. It was expected since this had a cement content higher than the other SC-added series. The compression strength for 7 and 28 days presented the same trend, as the higher the CS amount in the mixture, the lower was the compression strength until $20 \%$ of CS added, for $30 \%$ of CS addition, the strength increased in comparison with $20 \%$-added sample. One reason for this behavior may be as the higher the CS in the mixture, the lower was the binder quantity in the material, resulting in this behavior. However, for 28 days, only a marginal decrease in the compression strength was achieved. The control series presented $28.2 \mathrm{MPa}$, and the $10 \%$ and 30\% presented 24.5 and $25.9 \mathrm{MPa}$, respectively, that represents a decrease of 13 and $8.3 \%$ respectively in comparison with the control series. To clarify if the samples are similar, One-way ANOVA with Tukey test was made to compare if the CS-addition was influent in the compressive strength of the samples in 7 and 28 days of cement hydration. There was significant effect of amount of copper slag in compressive strength at $95 \%$ of confidence level (F-test: 35.72; p-value: $3.17 \times 10^{-8}$ and F-test: 40.80 ; p-value: $3.16 \times 10^{-9}$, for 7 and 28 days, respectively). Post hoc using the Tukey test indicated that, for 7 days of cement hydration, the average strength comparison between control series, $10 \%$ and $20 \%$ CS-added were significantly different. However, the average strength comparison between control series and 30\% CS-added did not significantly differ. For 28 days of cement hydration, the average strength comparison showed that all CS-added series were significantly different than control series. However, the average strength comparison between $10 \%$ and 30\% CS-added series did not significantly differ. These results indicated that the compressive strengths of concretes made with copper slag are similar as that of concretes or even quite lower than the control mixtures. This is interesting mainly due the competitive compressive achieved comparable to reference sample with a waste based material.

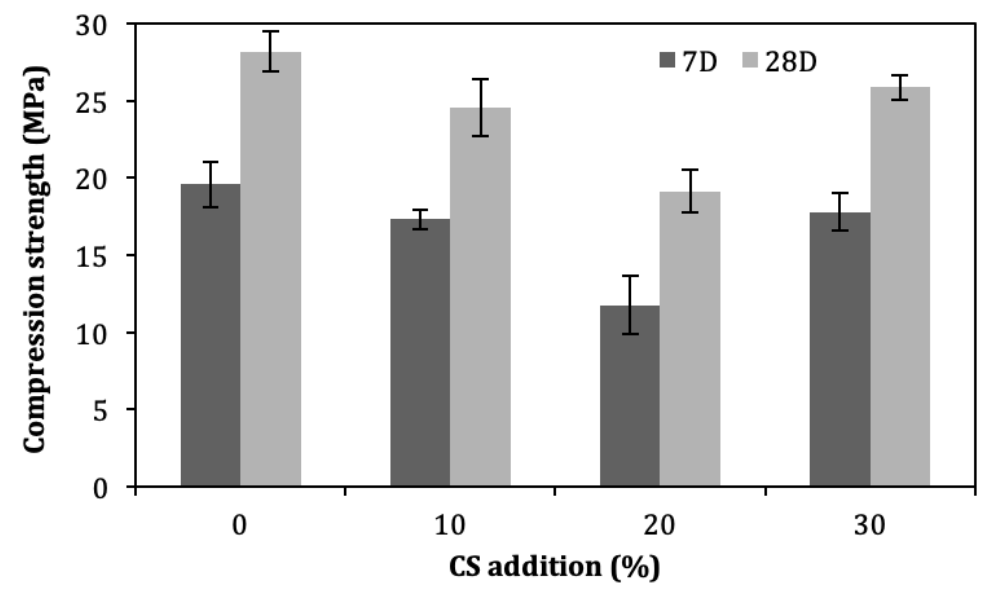

Figure 9: Average compression strength for 7 and 28 days with $0,10,20$ e $30 \%$ of CS addition. The error bars stand to standard deviation.

These results found here is in line with presented in $[1,23,21,25,20]$, however this results are different than found by AL-JABRI et al. [32], that verified a slight improvement in the mechanical strength of the concretes with CS addition until $40 \%$ of addition. This difference may be due the CS characteristics used in this research, that is coarser than used in AL-JABRI et al. [32] research. The coarser the aggregate, more void in the granular skeleton, that is translated in more macro porosity or necessity of cement paste to fill the space, and the porosity is one of the most influent effect in compressive strength in cementitious matrix $[37,38]$.

In Figure 10 is presented the cement index of the concretes produced with CS at 7 and 28 days of cement hydration and cement consumption of the concrete proportion [39]. The cement index measures the amount of cement per $\mathrm{m}^{3}$ of concrete for a unit of compressive strength, which means the quantity of the cement needs to achieve $1 \mathrm{MPa}$ of strength and is expressed in $\mathrm{kg} \cdot \mathrm{m}^{-3} \cdot \mathrm{MPa}^{-1}$. This index is useful to compare the mechanical performance of concretes with different cement contents. With the exception of the sample with $20 \%$ of copper slag, which showed a higher cement index due to it lower mechanical strength, mainly due to its lower workability in the fresh state, which impairs the homogenization of the mixture and enhances the macrodefects (such as porosity), compared to the other samples. As the higher the CS in the cementitious matrix lower was the binder amount and, consequently, the lower was the cement consumption of the mixture, as verified in Figure 10. In parallel, is possible to note that for 7 days of cement hydration, the 
control series achieved $16 \mathrm{~kg} \cdot \mathrm{m}^{-3} \cdot \mathrm{MPa}^{-1}$ while the $30 \% \mathrm{CS}$-added series presented only $17 \mathrm{~kg} \cdot \mathrm{m}^{-3} \cdot \mathrm{MPa}^{-1}$, that represents only $6.25 \%$ higher than control series, even consuming $30 \%$ of copper waste, reflecting in a good green concrete potential.

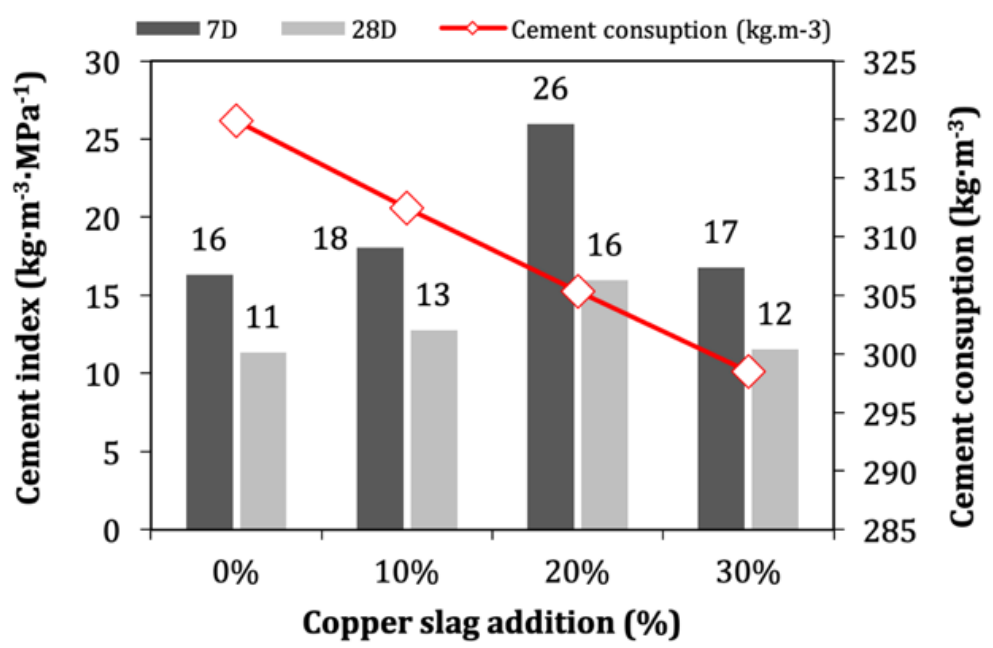

Figure 10: Cement index for 7 and 28 days with 0,10, 20 e $30 \%$ of CS addition and cement consumption.

In addition, for 28 days of cement hydration, the control series presented $11 \mathrm{~kg} \cdot \mathrm{m}^{-3} \cdot \mathrm{MPa}^{-1}$ and the $30 \%$ CS-added series presented $12 \mathrm{~kg} \cdot \mathrm{m}^{-3} \cdot \mathrm{MPa}^{-1}$, that is $9 \%$ higher than control series. The indices obtained for the concretes containing the residues are quite satisfactory, since they are close control series. These results demonstrate the good performance of the residue for the production of normal plastic concretes.

\section{CONCLUSIONS}

This work evaluated the feasibility of using copper slag (CS) as an additional material in normal plastic concretes. Based on the results presented in this paper, the following conclusions were established:

- With the slag additions used, there was a reduction of the slump and, consequently, there was a reduction of the concrete workability resulted in the more aggregate presence in the mixture.

- When analyzing the specific gravity of the concrete, it was observed that there was an increase as the addition of copper slag increases. However, this increase represents respectively $4 \%$ and $6 \%$ for the ages of 7 and 28 days of concrete, respectively, with $30 \%$ of CS addition.

- Regarding the absorption by immersion, the concretes with the addition of 20 and $30 \%$ showed better behavior for the ages of 28 days, less $19.06 \%$ and $17.97 \%$, respectively, compared to the control concrete. For capillary absorption, the concrete with copper slag addition showed a reduction in relation to the capillary absorption for the period of 48 hours, for the age of 28 days. Therefore, it is feasible to apply copper slag from a durability point of view, as it improves the permeability of water inside the system, thus reducing the possibility of transporting aggressive agents.

- Regarding the compressive strength, it was observed that there was a small decrease in relation to the reference concrete for all additions. However, the best result was the addition of $30 \%$ copper slag, which showed an average compressive strength reduction of only $9 \%$ for the concrete age of 7 days and $8 \%$ for the age of 28 days, and presented an increase of only $6 \%$ for the concrete age of 7 days and $9 \%$ for the age of 28 days for the ratio of cement consumption by strength, which that is very close to the reference concrete, nevertheless with high consumption of the residue material.

Overall, the addition of a $30 \%$ copper slag is the most feasible in this work, both from an environmental and economic point of view. However, more research should be made for copper slag addition or field storage. This material is a waste and has to be investigated by leaching and other complexes 
processes among additional chemical reactions between the environment and the cementitious matrix.

\section{ACKNOWLEDGMENT}

The authors would like to acknowledge the Laboratory of Civil Construction and Structures of the Federal University of Pernambuco for the support during the experimental program. We also would like to acknowledge the Brazilian governmental research agencies Coordination for the Improvement of Higher Education Personnel (CAPES) and the National Council for Scientific and Technological Development $(\mathrm{CNPq})$ for the financial support to laboratories involved in the research.

\section{REFERENCES}

[1] FENG, Y., YANG, Q., CHEN, Q., et al., "Characterization and evaluation of the pozzolanic activity of granulated copper slag modified with CaO", Journal of Cleaner Production, v. 232, pp. 1112-1120, 2019.

[2] GORAI, B., JANA, R.K., PREMCHAND., "Characteristics and utilization of copper slag - A review". Resources, Conservation and Recycling, v. 39, n. 4, pp. 299-313, 2003.

[3] STEFANOVIĆ, G.M., VUČKOVIĆ, G.D., STOJILJKOVIĆ, M.M., et al.,"CO2 reduction options in cement industry - The Novi Popovac case", Thermal Science, v. 14, n. 3, pp. 671-679, 2010.

[4] SALAS, D.A., RAMIREZ, A.D., RODRÍGUEZ, C.R., et al.,"Environmental impacts, life cycle assessment and potential improvement measures for cement production: A literature review", Journal of Cleaner Production, v. 113, pp. 114-122, 2016.

[5] VAN DAMME, H., "Concrete material science: Past, present, and future innovations". Cement and Concrete Research, no. May, pp. 0-1, 2018.

[6] RANDL, N., STEINER, T., OFNER, S., et al.,"Development of UHPC mixtures from an ecological point of view", Construction and Building Materials, v. 67, pp. 373-378, 2014.

[7] YU, R., SPIESZ, P., BROUWERS, H.J.H., "Development of an eco-friendly Ultra-High Performance Concrete (UHPC) with efficient cement and mineral admixtures uses", Cement and Concrete Composites, v. 55, pp. 383-394, 2015.

[8] CHEUNG, J., ROBERTS, L., LIU, J., "Admixtures and sustainability". Cement and Concrete Research, n. December, pp. 0-1, 2016.

[9] CASAGRANDE, C.A., JOCHEM, L.F., ONGHERO, L., et al.,Substituição parcial de superplastificante por TEOS em pastas cimentícias, In: Anais do 61 Congresso Brasileiro do Concreto. Fortaleza: Instituto Brasileiro do Concreto - IBRACON, pp. 1-8, 2019.

[10] JOCHEM, L.F., APONTE, D., BIZINOTTO, M.B., et al.,"Effects of pre-wetting aggregate on the properties of mortars made with recycled concrete and lightweight aggregates", Matéria (Rio de Janeiro), v. 24, n. 2019.

[11] DAMRONGSIRI, S., "Feasibility of using demolition waste as an alternative heavy metal immobilising agent", Journal of Environmental Management, v. 192, pp. 197-202, 2017.

[12] SINGH, M., SRIVASTAVA, A., BHUNIA, D., "An investigation on effect of partial replacement of cement by waste marble slurry", Construction and Building Materials, v. 134, pp. 471-488, 2017.

[13] SILVA, R. V., DE BRITO, J., LYNN, C.J., et al.,"Use of municipal solid waste incineration bottom ashes in alkali-activated materials, ceramics and granular applications: A review", Waste Management, v. 68, pp. 207-220, 2017.

[14] SÉRGIO FILHO, J., SINHORELLI, K., MEDEIROS, G., et al.,"Estudo da reologia de pastas cimentícias contendo resíduo de tijolo cerâmico moído e metacaulim", Matéria (Rio de Janeiro), v. 25, n. 1, 2020.

[15] AMANCIO, F.A., LIMA, D.A., DIAS, A.R. de O., et al.,"Propriedades mecânicas de argamassas com substituição da areia natural por escória de aciaria BSSF (baosteel's slag short flow)", Matéria (Rio de Janeiro), v. 25 , n. 1, 2020.

[16] KURZ, M.N., BRANDELLI, T.M., PALIGA, C.M., et al.,"A potencialidade do uso de resíduo de borracha de pneu em argamassa: análise das propriedades físicas e mecânicas", Matéria (Rio de Janeiro), v. 23, n. 3, 2018.

[17] CAMARINI, G., SOARES, S., "Propriedades de argamassas de cimento produzidas com resíduo de isolador de porcelana Properties of cement mortars with porcelain insulator waste", Revista Matéria, v. 23, n. 01, p. 15, 2018.

[18] ASSOCIAÇÃO BRASILEIRA DE NORMAS TÉCNICAS. NBR 16697 - Cimento Portland - Requisi- 
tos, 2018.

[19] JOCHEM, L.F., CASAGRANDE, C.A., ROCHA, J.C., "Effect of lead in mortars with recycled aggregate and lightweight aggregate", Construction and Building Materials, v. 239, pp. 117702, 2020.

[20] PAVEZ, O., NAZER, A., RIVERA, O., et al.," "Copper slag from different dumps in the Atacama Region used in mortars as partial replacement of cement", Revista Materia, v. 24, n. 2, 2019.

[21] DOS ANJOS, M.A.G., SALES, A.T.C., ANDRADE, N., "Blasted copper slag as fine aggregate in Portland cement concrete", Journal of Environmental Management, v. 196, pp. 607-613, 2017.

[22] GUPTA, N., SIDDIQUE, R., "Strength and micro-structural properties of self-compacting concrete incorporating copper slag", Construction and Building Materials, v. 224, pp. 894-908, 2019.

[23] WU, W., ZHANG, W., MA, G., "Optimum content of copper slag as a fine aggregate in high strength concrete", Materials and Design, v. 31, n. 6, pp. 2878-2883, 2010.

[24] AL-JABRI, K.S., HISADA, M., AL-ORAIMI, S.K., et al.,"Copper slag as sand replacement for high performance concrete", Cement and Concrete Composites, v. 31, n. 7, pp. 483-488, 2009.

[25] SHI, C., MEYER, C., BEHNOOD, A., Utilization of copper slag in cement and concrete, Elsevier, August, 2008.

[26] AMERICAN SOCIETY OF TESTING MATERIALS, "ASTM C150 / C150M - 19a - Standard Specification for Portland Cement", ASTM International, 2019.

[27] ASSOCIAÇÃO BRASILEIRA DE NORMAS TÉCNICAS, NBR 67 - Concreto - Determinação da consistência pelo abatimento do tronco de cone, 1998.

[28] ASSOCIAÇÃO BRASILEIRA DE NORMAS TÉCNICAS, NBR 5739 - Concreto - Ensaio de compressão de corpos de prova cilíndricos, 2018.

[29] ASSOCIAÇÃO BRASILEIRA DE NORMAS TÉCNICAS, NBR 9779 - Argamassa e concreto endurecidos - Determinação da absorção de água por capilaridade, 2012.

[30] RICARDO DE MATOS, P., DORS SAKATA, R., PRUDÊNCIO, R., "Eco-efficient low binder highperformance self-compacting concretes", Construction and Building Materials, v. 225, pp. 941-955, 2019.

[31] CASAGRANDE, C.A., CAVAlARO, S.H.P., REPETTE, W.L., "Ultra-high performance fibrereinforced cementitious composite with steel microfibres functionalized with silane", Construction and Building Materials, v. 178, pp. 495-506, 2018.

[32] AL-JABRI, K.S., AL-SAIDY, A.H., TAHA, R., "Effect of copper slag as a fine aggregate on the properties of cement mortars and concrete", Construction and Building Materials, v. 25, n. 2, pp. 933-938, 2011.

[33] MOURA, W.A., GONÇALVES, J.P., LIMA, M.B.L., "Copper slag waste as a supplementary cementing material to concrete", Journal of Materials Science, v. 42, n. 7, pp. 2226-2230, 2007.

[34] SHARMA, R., KHAN, R.A., "Sustainable use of copper slag in self compacting concrete containing supplementary cementitious materials", Journal of Cleaner Production, v. 151, pp. 179-192, 2017.

[35] SINGH, L.P., BHATTACHARYYA, S.K., SHAH, S.P., et al.,"Studies on early stage hydration of tricalcium silicate incorporating silica nanoparticles: Part II", Construction and Building Materials, v. 102, pp. 943-949, 2016.

[36] KHANZADI, M., BEHNOOD, A., "Mechanical properties of high-strength concrete incorporating copper slag as coarse aggregate", Construction and Building Materials, v. 23, n. 6, pp. 2183-2188, 2009.

[37] CASAGRANDE, C.A., JOCHEM, L.F., ONGHERO, L., et al., "Effect of partial substitution of superplasticizer by silanes in Portland cement pastes", Journal of Building Engineering, v. 29, pp. 101226, 2020.

[38] CHEN, X., WU, S., ZHOU, J., "Influence of porosity on compressive and tensile strength of cement mortar", Construction and Building Materials, v. 40, pp. 869-874, 2013.

[39] MATOS, P.R., PRUDÊNCIO JR, L.R., OLIVEIRA, A.L., et al.,"Use of porcelain polishing residue as a supplementary cimentitious material in self-compacting concrete", Construction and Building Materials, v. 193, pp. 623-630, 2018.

\section{ORCID}

Cézar Augusto Casagrande Diego Deyvison dos Santos Lidiane Fernanda Jochem Ana Cecília de Nóbrega http://orcid.org/0000-0002-4293-6574

https://orcid.org/0000-0003-4446-9065

https://orcid.org/0000-0001-6679-2897

https://orcid.org/0000-0003-1118-1911 